\title{
Moral luck and the unfairness of morality
}

\author{
Robert J. Hartman ${ }^{1}$
}

Published online: 18 September 2018

(C) The Author(s) 2018

\begin{abstract}
Moral luck occurs when factors beyond an agent's control positively affect how much praise or blame she deserves. Kinds of moral luck are differentiated by the source of lack of control such as the results of her actions, the circumstances in which she finds herself, and the way in which she is constituted. Many philosophers accept the existence of some of these kinds of moral luck but not others, because, in their view, the existence of only some of them would make morality unfair. I, however, argue that this intermediary approach is unstable, because either morality is fair in ways that rule out resultant, circumstantial, and constitutive moral luck (and this leads to moral responsibility skepticism), or morality is unfair in ways that permit the existence of those kinds of moral luck. Thus, such intermediary approaches lack the motivation that their proponents have long taken them to have. In the appendix, I point to ways in which morality is unfair concerning the scope of moral responsibility, moral obligation, moral taint, being a good or bad person, and flourishing.
\end{abstract}

Keywords Moral luck · Luck · Moral responsibility · Free will · Fairness · Morality $\cdot$ Taking responsibility $\cdot$ Moral taint $\cdot$ Flourishing

Moral luck occurs when factors beyond an agent's control positively affect the degree of praise or blame she deserves. ${ }^{1}$ Kinds of moral luck are differentiated by

\footnotetext{
1 Moral luck is often defined in a broader way such that it occurs when factors beyond an agent's control affect her moral status (Anderson 2011, p. 373; Nagel 1979, p. 26; Hanna 2014, p. 683). Philosophers

Robert J. Hartman

roberthartman122@gmail.com

1 University of Gothenburg, Gothenburg, Sweden
} 
the source of lack of control such as the results of her actions, the circumstances in which she finds herself, and the way in which she is constituted (Nagel 1979, p. 28). ${ }^{2}$ Many philosophers allow some of those three kinds of moral luck to exist but not others, and a popular reason why is that if certain kinds of moral luck were to exist, morality would be unjust or unfair (Statman 1993, pp. 2, 3). I, however, argue that this intermediary approach is unstable, because either morality is fair in ways that rule out resultant, circumstantial, and constitutive moral luck (and this leads to moral responsibility skepticism), or morality is unfair in ways that permit the existence of all three kinds of moral luck. But then, the most common positions in the moral luck debate-namely, the positions that affirm some kinds of moral luck and deny others - cannot appeal to the unfairness objection to motivate their denial of only some kinds of moral luck. Thus, such intermediary approaches lack the motivation that their proponents have long taken them to have.

I proceed as follows. In the first two sections, I define and illustrate the canonical kinds of moral luck, and present the strongest version of the unfairness objection to moral luck. After these explications, I present a more precise outline of my argument. In the next three sections, I consider several intermediary positions on moral luck and argue that each is unmotivated with respect to the ideal of fairness. I offer some concluding thoughts, and, subsequently, I provide an appendix on several ways in which morality is unfair with respect to moral properties other than degree of praiseworthiness and blameworthiness.

\section{Categories of moral luck}

Thomas Nagel's (1979, p. 28) taxonomy of moral luck includes resultant, circumstantial, constitutive, and causal moral luck. ${ }^{3}$ Resultant moral luck occurs when an agent performs an action or omission with a consequence that is at least partially beyond her control and that consequence positively affects her praiseworthiness or blameworthiness. By 'positively affects', I mean that the luck at issue does not undermine praiseworthiness or blameworthiness. ${ }^{4}$ Here is an example. Killer, our first character, is at a party and drives home drunk. At a certain point in

Footnote 1 continued

writing on moral luck, however, tend to focus on the particular moral status of deserved praise and blame. For expositional simplicity, I have defined moral luck to focus on this particular moral status. Importantly, however, there are other kinds of moral luck where the 'moral' refers to moral obligation, virtue, flourishing, or some other moral property, and I consider several of these other moral properties in the appendix.

2 I consider Nagel's fourth kind of moral luck involving causal determinism in the next section.

3 The term 'resultant luck' is from Zimmerman (1987, p. 376), and 'causal luck' is from Statman (1993, p. 11).

4 This part of my definition is in keeping with the italicized part of Nagel's (1979, p. 26) own idea: "[A] significant aspect of what someone does depends on factors beyond his control, [and] yet we continue to treat him in that respect as an object of moral judgment" (italics mine). One way in which my definition departs from Nagel's is that it focuses on praiseworthiness and blameworthiness, and not praising and blaming. 
her journey, she swerves, hits the curb, and kills a pedestrian who was on the curb. Merely Reckless, our second character, is exactly like Killer in every way, but, when she swerves and hits a curb, she kills no one. There was no pedestrian on the curb for her to kill. The difference between Killer and Merely Reckless is a matter of luck. Is Killer more blameworthy - that is, does she deserve more blame-than Merely Reckless? If Killer is more blameworthy, this would be a case of resultant moral luck, and if they are equally blameworthy, this would not be a case of resultant moral luck.

Circumstantial moral luck occurs when it is outside of the agent's control whether she faces a morally significant challenge or opportunity, and it positively affects her praiseworthiness or blameworthiness. Here are two more examples. No Start, our third character, gets drunk and gets into her car in exactly the same way as our first two characters, but the difference is that her car does not start. As a result, she has to call a cab to take her home. But if No Start's engine had turned over, she would have driven drunk just as they did. By stipulation, it is beyond No Start's control that her car fails to start, and it is outside of Merely Reckless's control that her car does start. Works Tonight, our fourth character, has the same moral character as Killer, Merely Reckless, and No Start, and so Works Tonight would have gotten drunk and driven home if she had gone to the party as she had planned. Works Tonight, however, was called in to work, and was thereby saved from disgrace. Of course, it is a matter of luck that Works Tonight was called into work, and that the other three were not. Are No Start and Works Tonight as blameworthy as Merely Reckless? ${ }^{5}$ If Merely Reckless is more blameworthy than No Start and No Start is more blameworthy than Works Tonight, then circumstantial moral luck would exist in both cases, because luck in opportunity would make a moral responsibility-relevant difference. If, however, all three of them are equally blameworthy, then circumstantial moral luck would not exist in these cases; and all three would be exactly as blameworthy as Killer too if resultant moral luck also does not exist.

Constitutive moral luck occurs when an agent's dispositions or capacities are not voluntarily acquired, and they positively affect her praiseworthiness or blameworthiness for a trait or an action. Scarred Childhood, our fifth character, had a father who was killed by a drunk driver, and she subconsciously developed the policy never to drive drunk. If that traumatic experience had not occurred, however, Scarred Childhood would have had a different character and would have formed the intention to drive drunk at the party as the others do. Of course, it is outside Scarred Childhood's control that she had this traumatic experience, and it is outside of Killer, Merely Reckless, No Start, and Work Tonight's control that they never had that kind of traumatic experience. Is Scarred Childhood as blameworthy as the

\footnotetext{
5 Why use two cases of circumstantial luck? Whether the case of Merely Reckless and No Start is a case of circumstantial or resultant luck depends on what actions are (see Nelkin 2013). If actions are purely mental events, it would be a case of resultant luck; they performed the same mental actions with different consequences. If actions are overt bodily actions, it would be a case of circumstantial luck, because they would have performed the same actions in the same circumstances but were not in the same circumstances.
} 
others? If Merely Reckless and No Start are each more blameworthy than Scarred Childhood, then constitutive moral luck would exist in this case. But if all five of our characters turn out to be equally blameworthy, then there would be no constitutive moral luck (and no circumstantial and resultant moral luck either). ${ }^{6}$

Causal moral luck occurs when the laws of nature and past states of affairs that are outside of a person's control causally determine what she does, and thereby positively affect her praiseworthiness or blameworthiness. ${ }^{7}$ The question of whether causal moral luck could exist is the same question as whether an action's having been causally determined is compatible with being morally responsible for that action, which is a standard topic in the free will literature. The moral luck debate proper, however, is about resultant, circumstantial, and constitutive moral luck, because these are the kinds of luck that make the problem of moral luck a distinctive problem. ${ }^{8}$ Although it can be illuminating to consider whether causal moral luck exists alongside these three (see Hartman 2017, pp. 53-55, 71-80), I ignore this complexity about causal moral luck for the time being, and return to it at the conclusion of the essay.

\section{The absolute fairness objection to moral luck}

The strongest version of the unfairness objection to moral luck is that it is unfair for any one of Killer, Merely Reckless, No Start, Works Tonight, and Scarred Childhood to be more blameworthy than any of the others, because the salient difference between them is a matter of luck and morality must be protected from all kinds of luck. ${ }^{9}$

The nature of this absolutely fair conception of morality involves a requirement for total equality of moral opportunity and a kind of pure agency. ${ }^{10}$ According to Bernard Williams's (1981, p. 21) description of that conception, "The successful moral life ... is presented as a career open not merely to the talents, but to a talent which all rational beings necessarily possess in the same degree." Thus, bad upbringings, tumultuous circumstances, and tragic consequences are not factors that foreclose opportunities to live successful moral lives; they do not even make it more difficult to do so. As Williams asserts,

\footnotetext{
${ }^{6}$ I take this claim to be compatible with the skeptical position that none of them are blameworthy for anything. See, for example, Levy (2011), Strawson (1994), and Waller (2011).

7 Causal luck could be defined in a broader way to include also the indeterminism highlighted by the luck objection to libertarianism (cf. Mele 2006; van Iwagen 2002). I ignore this complexity.

8 For more about the distinctiveness of these problems, see Hartman (2017, pp. 4-9).

9 It is not uncommon for philosophers to appeal to fairness as a norm that governs desert, blameworthiness, and being responsible (Levy 2014, p. 126; Rosen 2002; Wallace 1994). For a challenge to Wallace (1994) and Rosen (2002), see Graham (2014).

10 The term "absolutely fair" is from Russell (2008, p. 316). And as Otsuka (2009, p. 374) recognizes, 'morality' in this context refers only to praiseworthiness and blameworthiness, and not also to other moral properties such as moral virtue and vice.
} 
Anything which is the product of happy or unhappy contingency is no proper object of moral assessment, and no proper determinant of it, either (1981, p. 20).

There is pressure within it [our conception of morality] to require a voluntariness that will be total and will cut through character and psychological or social determination, and allocate blame and responsibility on the ultimately fair basis of the agent's own contribution, no more and no less (1985, p. 194).

On this absolutely fair view, the moral praise and blame that we deserve cannot be conditioned by lucky factors outside of our control such as our genetic make-up, moral training, social pressure, opportunity, results, and the like. ${ }^{11}$ It seems very plausible to think that an agent can be morally responsible on this view only if she created herself out of nothing, because it is only then that her agency would be pure in the right kind of way and everyone would have the very same moral opportunities to deserve praise and avoid blame, at least with respect to their interior constitution. This strong self-creation condition on morally responsible agency, however, cannot possibly be satisfied (see Strawson 1994). So, the absolutely fair conception of morality not only implies that no resultant, circumstantial, or constitutive moral luck exist, but also that it is impossible for anyone to be morally responsible for anything.

Williams rejects the absolutely fair conception of morality, regarding the impossibility of satisfying it as a reductio. Other philosophers such as Nagel and Galen Strawson, however, accept these fairness-based requirements as a deliverance of common sense. On the one hand, Nagel (1979, p. 34) endorses a paradox, because he affirms these requirements that are impossible to satisfy and still believes that we are morally responsible for at least some of what we do. On the other hand, Strawson (1994) straightforwardly concludes from those requirements that it impossible to be morally responsible for anything (cf. Levy 2011; Waller 2011).

Most philosophers in the moral luck debate part ways with Nagel and Strawson precisely because they believe that it is at least metaphysically possible for us to be morally responsible agents without affirming a Nagelian paradox. These philosophers allow at least some kinds of moral luck to exist in order to support morally responsible agency, but many of them deny that certain other kinds of moral luck exist on the grounds that their existence would make morality unfair. Over the next three sections, I argue that the fairness-based justification for such intermediary views is unstable, because there is no fairness-relevant difference between the kinds of moral luck that they accept and the kinds that they reject. If my argument is successful, then the proponents of these intermediary views should either (1) embrace absolute fairness as the standard of morality, and so embrace responsibility skepticism or the Nagelian paradox, or (2) agree that there is no good objection to constitutive, circumstantial, or resultant moral luck on grounds of fairness. In Hartman (2017, forthcoming), I argue against taking the first horn (see also Sher 2005; Russell 2008, 2017). If philosophers who occupy these intermediary positions take the second horn, at least some of them

\footnotetext{
11 Not everyone in the moral responsibility literature accepts the assumptions about control that animate the problem of moral luck. See, for example, Smith (2005) and McKenna (2008).
} 
will have good motivation to abandon their positions, because a common motivation for rejecting moral luck is on grounds of fairness. ${ }^{12}$

\section{Allowing only essential constitutive moral luck}

A central feature of Michael Zimmerman's (2002, pp. 560, 561) response to the problem of moral luck distinguishes between the "degree" and "scope" of moral responsibility (cf. Peels 2015, p. 74). The degree of moral responsibility is about how much praise or blame a person deserves, and this kind of moral responsibility is luck-free. But the scope of responsibility concerns the events for which an agent is morally responsible, and this sense of moral responsibility is not luck-free. Zimmerman uses the degree/scope distinction as well as true subjunctive conditionals of freedom to eliminate all resultant and circumstantial moral luck and almost all constitutive moral luck. ${ }^{13}$

Let us start with the way in which Zimmerman uses the degree/scope distinction to eliminate resultant moral luck. Because the only difference between Killer and Merely Reckless is a matter of luck and luck is irrelevant to degree of moral responsibility, the degree of their moral responsibility is the same (Zimmerman 2002, pp. 560-562; cf. Enoch and Marmor 2007, pp. 408-420; Peels 2015, p. 83). But the scope of their moral responsibility differs, because only Killer is morally responsible for the death of a pedestrian. Killer is morally responsible for more things, but they are equally blameworthy. Thus, no resultant moral luck exists in this case, because the actual results of a person's actions that are outside of her control do not affect her degree of praiseworthiness or blameworthiness.

Next, consider the way in which Zimmerman uses the degree/scope distinction and true subjunctive conditionals of freedom to eliminate circumstantial moral luck. Because the salient difference between Merely Reckless, No Start, and Works Tonight is a matter of luck with respect to whether the car starts or having to work, the degree of their moral responsibility is the same; all three are equally blameworthy (Zimmerman 2002, pp. 564, 565; cf. Enoch and Marmor 2007, pp. 420-425; Peels 2015, pp. 79, 80). Nevertheless, the scope of their moral

\footnotetext{
12 My argument is similar in various ways to Moore's (1997) argument for resultant moral luck. Here is Moore's argument: if resultant moral luck does not exist, then circumstantial, constitutive, and causal moral luck do not exist either. Nevertheless, at least circumstantial, constitutive, or causal moral luck exists. Therefore, resultant moral luck also exists. Moore (1997, p. 237) justifies the conditional by claiming that "luck is luck, and to the extent that causal fortuitousness is morally irrelevant anywhere it is morally irrelevant everywhere." My argument differs from Moore's in at least three ways. First, my argument better captures the dialectic of the problem of moral luck, because I make impossibilism the extreme luck-free position, whereas Moore suggests that it is incompatiblism. Second, my argument makes no dubious assumption that there is no morally relevant difference between any kinds of luck (see Coffman 2015, pp. 110-111; Hartman 2017, p. 105). Third, my weaker conclusion is that denying only some kinds of moral luck due to unfairness is untenable, whereas Moore's stronger conclusion is for the existence of moral luck.

13 In Hartman (2017, pp. 71-80), I offer an argument that subjunctive conditionals of direct libertarian freedom are necessarily false, and show that different kinds of subjunctive conditionals of freedom that might be true are ill-suited for Zimmerman's account of moral responsibility.
} 
responsibility differs. Merely Reckless is morally responsible for driving drunk, and No Start is morally responsible for forming the intention to drive drunk. But Works Tonight is not morally responsible for anything related to drunk driving. How, then, can Works Tonight be as blameworthy as the others? Zimmerman's (2002, pp. 564, 565) answer is that Works Tonight is blameworthy "tout court" or simpliciter in virtue of the fact that she would have freely driven drunk as Merely Reckless does if she had not been called into work. Thus, no circumstantial moral luck exists in these cases, because which of the circumstances outside of their control are actual does not affect their degree of praiseworthiness or blameworthiness.

Finally, consider the way in which Zimmerman's view eliminates most constitutive moral luck. Because the salient difference between Merely Reckless and Scarred Childhood is luck in formative history, they are equally blameworthy (Zimmerman 2002, pp. 574, 575). Even though Scarred Childhood's moral responsibility has no scope, she is blameworthy in virtue of what she would have freely done if she had had a different formative history in which her parent was not killed by a drunk driver. So then, no constitutive moral luck exists in this case, because which of an agent's constitutive properties outside of her control are actual does not affect her degree of praiseworthiness or blameworthiness.

Zimmerman appeals to fairness to motivate this ethical outlook (Hanna 2014, pp. 692-694). Zimmerman (2002, p. 559) contends that the following general principle is intuitively attractive: "[T]he degree to which we are morally responsible cannot be affected by what is not in our control. Put more pithily: luck is irrelevant to moral responsibility." Morality would, after all, be unfair if the degree to which we are morally responsible were determined by something other than what is under the agent's control. As Zimmerman writes,

If there is unfairness in the differential judgments [for example, Merely Reckless is more blameworthy than Works Tonight]_as I believe there is ... then this unfairness ... [consists] in ascribing moral responsibility to one ... but not ascribing it to the other (1987, p. 382; italics mine; see also his 1988, p. 136).

I think there may be a (perhaps metaphorical) sense in which it would be unfair if Bill were more culpable than Ben [Bill and Ben are snipers, only one of which kills his mark due to luck] (2015, p. 156; italics mine).

Likewise, Zimmerman would say that it would be unfair if Merely Reckless were more blameworthy than Scarred Childhood due to features of their formative history outside of their control. Let us refer to the conception of fairness operative here as subjunctive fairness. If persons $\mathrm{S}$ and $\mathrm{S}^{*}$ are actually or subjunctively exactly alike with respect to some event $x$ except regarding factors that are outside of their control, then it would be unfair if they were to be praiseworthy or blameworthy to different degrees with respect to $x$. $^{14}$

Zimmerman (2002, p. 575), however, concedes that his use of subjunctive conditionals of freedom may not be able to eliminate all constitutive moral luck,

\footnotetext{
14 This principle is a revised version of one presented in Greco (1995, p. 89). Notably, Greco rejects the principle, and affirms resultant, circumstantial, and constitutive moral luck (see Hartman 2017, Ch. 6).
} 
because at least some of our personal characteristics may be essential to us. That is, Zimmerman recognizes that we cannot coherently appeal to what a particular person would freely do in circumstances in which she does not have a particular essential property or in which she has different essential properties in order to neutralize her essential constitutive moral luck, since it would not be her if she lost an essential property or had different essential properties. Thus, essential constitutive moral luck cannot be eliminated, and essential features of a person's character outside of her control can affect the praise and blame she deserves by inclining her to perform and forgo various kinds of action. If different persons have different essential constitutive luck, it is impossible for everyone to be in the same counterfactual circumstances, which implies that there is no absolute equality of moral opportunity.

Zimmerman offers no proposal for eliminating essential constitutive moral luck. Nevertheless, there is good reason to think that he is committed to denying even this undeniable kind of constitutive moral luck. Since contingent constitutive luck involves a kind of lack of control that is pernicious with respect to the fairness of morality and since essential constitutive luck involves a similar lack of control, we should expect that essential constitutive luck is also pernicious in a similar way.

One might object that a relevant difference between these kinds of constitutive luck is that there is no luck involved in the so-called 'essential constitutive luck', because lucky states of affairs must be contingent (see Rescher 1993, pp. 155-157). But this reply cannot help. Zimmerman (2002, p. 559, cf. 2015, p. 136) uses the lack of control definition of luck, and both contingent and essential properties may be outside of the agent's control in the relevant sense. Furthermore, I argue in Hartman (2017, pp. 23-31) that we should use the lack of control conception of luck in the moral luck debate, because it is only this conception that generates the distinctive puzzle involved in the problem of moral luck (see also Anderson forthcoming; Statman forthcoming). ${ }^{15}$

One might also object that there can be no unfairness about which essential properties a person has, and this consideration points to a relevant difference between these modal varieties of constitutive luck. Zimmerman, however, would not agree. He thinks, for example, that the capacity to act freely is an essential property (2002, p. 575) and that it is "unfair" that "an unfree object (whether animate or not) never has the opportunity to distinguish itself (or to disgrace itself) in such a way as to deserve praise (or blame)" (1987, p. 385n25). This is precisely the sort of response we should expect of someone who aims to neutralize luck from affecting degree of praiseworthiness and blameworthiness.

Finally, one might object that because it is not metaphysically possible to eliminate essential constitutive moral luck, it poses no threat to the fairness of morality. This objection, however, cannot be right either, because the argument contains only a metaphysical reason that explains why essential constitutive moral luck cannot be eliminated. The argument does not give fairness-relevant moral reasons why essential constitutive moral luck does not need to be eliminated to preserve the fairness of morality, while contingent constitutive moral luck must be.

\footnotetext{
15 For explication and defense of various conceptions of luck including the lack of control account, see Church and Hartman (forthcoming).
} 
Allow me to motivate these claims. Suppose, as I have argued in Hartman (2017, pp. 71-82), that Zimmerman is committed to the truth of subjunctive conditionals of freedom that are metaphysically contentious in order to eliminate circumstantial and contingent constitutive moral luck. If it turned out that all such conditionals are necessarily false, we would not thereby conclude that circumstantial and contingent constitutive luck to which agents would still be subject can affect moral responsibility, because those kinds of luck should still be irrelevant to moral responsibility; they would still be pernicious to moral evaluation. By analogous reasoning, even if the subjunctive conditionals of freedom that would be able to neutralize essential constitutive moral luck are necessarily false, essential constitutive luck would still be problematic. ${ }^{16}$

Therefore, it seems plausible that there is no fairness-relevant moral reason to affirm the subjunctive fairness conception of morality and to deny the absolute fairness conception of morality on the assumption that at least some of our personal characteristics are essential to us. ${ }^{17}$ Thus, the motivation for Zimmerman's account is unstable in this way. ${ }^{18}$ Either he should embrace the absolute fairness conception of morality and so embrace moral responsibility skepticism or the Nagelian paradox, or he should accept that morality is unfair in a way that permits the existence of contingent constitutive moral luck. Over the next two sections, however, I argue that the latter option also involves agreeing that morality is unfair in ways that allow for the existence of circumstantial and resultant moral luck.

\section{Denying some circumstantial and constitutive moral luck}

Rik Peels $(2015,2017)$ argues for a modest version of Zimmerman's view in which no resultant moral luck exists, and only some kinds of circumstantial and constitutive moral luck do not exist. ${ }^{19}$ Peels (2017, p. 220) agrees with Zimmerman to the extent that at least some kinds of resultant, circumstantial, and constitutive moral luck would make morality "unfair" (cf. 2017, p. 222). The modesty in Peels's (2015) view, however, comes from a desire to avoid what he sees as an absurd implication of Zimmerman's account—namely, that a person can be blameworthy in virtue of what she would freely do in modally distant circumstances even with character traits different from those she has in the actual world.

To avoid this implication, Peels (2015, p. 77) appeals to an account of luck that augments the lack of control account in the following way: an event $e$ is lucky for a

\footnotetext{
${ }^{16}$ Why not just think that Zimmerman is defending a luck-free view insofar as it is consistent with possibilism? According to the dialectic, however, this is not a legitimate approach without an argument for possibilism (and Zimmerman provides no such argument), because my argument is that the view that luck is irrelevant to moral responsibility inevitably leads to impossibilism or the Nagelian paradox.

17 Coffman (2015, pp. 104-115) nicely argues that Zimmerman's account of moral responsibility presupposes the falsity of what I am calling the absolutely fair conception of morality.

18 For a similar point, see Rosell (2015, pp. 128-129).

19 Enoch and Marmor (2007) also espouse a modest version of Zimmerman's view, but do so in a way that differs from Peels in particular ways. Interestingly, Enoch and Marmor do not motivate their view by any explicit appeal to fairness; elsewhere, Enoch (2010, p. 46) suggests that appealing to fairness is merely a colorful way of stating the general anti-moral luck intuition.
} 
person if and only if (1) $e$ is significant for her, (2) she lacks control over $e$, and (3) $e$ could easily have failed to occur (cf. Peels forthcoming). To put condition (3) more precisely, an event $e$ satisfies this modal condition if and only if $e$ occurs in the actual world but fails to occur in a broad range of close possible worlds in which the relevant initial conditions are the same. For simplicity, let us refer to Peels's tripartite account as 'luck*' and the standard lack of control account as 'luck'. The modal condition limits lucky* events to those that occur in the actual world and nearby possible worlds. Since, then, it is not a matter of luck* what an agent would be or do in a distant possible world, Peels's account does not imply that an agent can be blameworthy with respect to counterfactual free actions in a distant possible world. In concrete terms, Peels's view implies that Merely Reckless and No Start are equally blameworthy, and that both are more blameworthy than Scarred Childhood. It is a matter of luck* that No Start fails to find herself in Merely Reckless's circumstance, but it is not a matter of luck* that Scarred Childhood fails to find herself in Merely Reckless's situation. The possible world in which Scarred Childhood is in a circumstance like Merely Reckless or No Start is not close to the actual world at that particular time given all the character and historical changes that would be required to put her in the same circumstance.

Peels's view of moral responsibility, then, eliminates all circumstantial and constitutive moral luck*, but it leaves a lot of circumstantial and constitutive moral luck intact. After all, most of the situations in which it is possible for us to be are situations in distant possible worlds. For this reason, Peels's view eliminates only a very small proportion of cases of circumstantial and contingent constitutive moral luck in comparison with Zimmerman's view.

Importantly, Peels uses the modal condition in his account of luck*-and so appeals to a metaphysical reason - to distinguish the circumstantial and constitutive moral luck* that cannot exist from the remaining circumstantial and constitutive moral luck that morality does permit. He, however, offers no fairness-relevant moral reason to justify this division (cf. Hartman 2017, pp. 25-29; 65, 66); after all, what fairness-relevant moral reason could he appeal to in order to justify differential blameworthiness between Merely Reckless and No Start, on the one hand, and Scarred Childhood, on the other? Peels's distinction between problematic circumstantial and constitutive moral luck* and benign circumstantial and constitutive moral luck, then, is unmotivated with respect to the ideal of fairness. Although I have my doubts about whether there is any plausible way to motivate Peels's distinction, my point here is merely that appealing to fairness cannot do it.

\section{Denying only resultant moral luck}

The most popular position in the moral luck debate is that circumstantial and constitutive moral luck do exist but that resultant moral luck does not. ${ }^{20}$ Call this position the Asymmetry View. In concrete terms, the view is that Killer and Merely

\footnotetext{
${ }^{20}$ The denial of resultant moral luck has been called "the Standard View" (Mackenzie 2017, p. 95) and "the Orthodox View" (Ferrante 2009, p. 276), and their assessment is corroborated by my own catalogue of published opinions (see Hartman 2017, p. 129).
} 
Reckless are equally blameworthy. Nevertheless, Merely Reckless is more blameworthy than No Start, because only Merely Reckless drives drunk; and No Start is more blameworthy than Works Tonight and Scarred Childhood, because only No Start intends to drive drunk. According to this view, there is a morally significant difference between the kinds of luck that rule out two agents from performing the same kind of action or omission and the sort of luck that operates after two agents perform the same kind of action or omission.

A common justification for the Asymmetry View is that it would be unjust or unfair for Killer to deserve more blame than Merely Reckless but not for Merely Reckless to deserve more blame than Works Tonight (Swenson manuscript; Wolf 2001 , p. 6, 18). ${ }^{21}$ On this actualist fairness conception of morality, if persons $\mathrm{S}$ and $\mathrm{S}^{*}$ are actually exactly alike with respect to some event $x$ except regarding factors that are outside of their control, then it would be unfair if they were to be praiseworthy or blameworthy to different degrees with respect to $x$. So, because Killer and Merely Reckless actually operate their vehicles in the same way, it would be unfair if they were to deserve different degrees of blame. ${ }^{22}$

One might argue for the claim that the fairness of morality rules out only resultant moral luck in part by showing that extant circumstantial and constitutive moral luck is compatible with total equality of moral opportunity. That is, there is no deep unfairness in accepting circumstantial and constitutive moral luck because all persons enjoy equality of moral opportunity, but there would be such unfairness in accepting resultant moral luck (Swenson manuscript). Roger Crisp (2017, p. 17) explores this idea by suggesting that it is always open to agents to do the right thing, and the degree of a person's praiseworthiness or blameworthiness for an action is in part determined by the difficulty involved in doing the right thing:

A harder choice may be more praiseworthy, so to this extent the circumstantial bad moral luck of the man who stayed in [Nazi] Germany was counterbalanced by the greater moral opportunities available to him. And as it becomes more difficult to make the correct choice, so it becomes a lesser wrong [and the agent less blameworthy] not to make it.

So, the person who faces bad circumstantial or constitutive luck finds herself in higher stakes situations in which it is harder to do the right thing. And because the likelihood of her doing the right thing is generally lower in higher stakes situations all other things being equal, she will be more praiseworthy if she does the right thing

\footnotetext{
21 Wolf (1990) affirms the existence of circumstantial and constitutive moral luck in other writings; in fact, the existence of circumstantial and constitutive moral luck is an entailment of her broader compatibilist commitments (see Hartman 2017, pp. 54, 55). Various other philosophers reject resultant moral luck as unjust or unfair without specifying whether they accept circumstantial and constitutive moral luck (Cushman and Greene 2012, p. 273; Parker 1984, p. 274).

22 A different justification of the Asymmetry View is that attributability accounts of moral responsibility imply the denial of only resultant moral luck (Khoury 2018; Talbert 2017). See Levy (2011, pp. 180-212) for an argument against attributability views. Yet another justification is that we should accept moral luck if and only if it is required for being morally responsible for actions, and admitting resultant moral luck is not necessary for being morally responsible for actions-but admitting circumstantial and constitutive moral luck is (Rivera-López 2016). See Hartman (2017, pp. 107-109) for a response to Rivera-López.
} 
and less blameworthy if she does the wrong thing. The opposite, of course, holds in lower stakes situations. Since the likelihood of her doing the right thing is generally higher in circumstances in which it is easier to do the right thing all other things being equal, she will be less praiseworthy if she does the right thing and more blameworthy if she does the wrong thing. So, one might think that this kind of equality of moral opportunity shows that there is no unfairness involved in accepting circumstantial and constitutive moral luck (Swenson manuscript). ${ }^{23}$

I, however, challenge the claim that there is equality of moral opportunity even if we suppose that agents can always do the right thing and that degrees of praiseworthiness and blameworthiness are sensitive to degrees of difficulty. First, higher and lower stakes circumstances involve different kinds of moral risks. And as Linda Zagzebski (1994, p. 409) argues, "[w]e do not get to decide initially how much of a risk we want to take," because it is often not up to us whether we find ourselves in higher or lower stakes circumstances. Someone who finds herself in certain higher stakes circumstances by luck may make choices that result in her being overall more praiseworthy and/or less blameworthy than if she had made choices in particular lower stakes circumstances. Likewise, someone who finds herself in certain lower stakes circumstances by luck may make choices that result in her being overall more praiseworthy and/or less blameworthy than if she had made choices in particular higher stakes circumstances. Herein lies a remaining source of unfairness. Second, I am dubious that weighting difficulty in proportion to degrees of praiseworthiness and blameworthiness could ever be precise enough to grant everyone equal moral opportunities (Zagzebski 1994, p. 409). To be clear, I am not saying that it is impossible to do the math; I am expressing doubt that degrees of praiseworthiness and blameworthiness are as fine-grained as the math requires. Thus, the suggestion that accepting circumstantial and constitutive moral luck as well as difficulty-weighted praiseworthiness and blameworthiness generates universal equality of moral opportunity is not a promising suggestion. I conclude that this kind of partial fairness-based justification for the Asymmetry View fails.

Let us turn to consider my positive argument for why there is no good fairnessbased justification for the Asymmetry View. The basic argument is that the features that make circumstantial and constitutive moral luck benign with respect to morality are also present in cases of resultant moral luck, which makes it benign too. It is helpful to think through this claim concretely with Killer and Merely Reckless as the case of resultant luck, and Merely Reckless and Works Tonight as the case of circumstantial luck. $^{24}$

There are two plausible moral principles that provide a minimal kind of core fairness that is required for moral responsibility, and both principles are asymmetrically satisfied in a way that differentiates the blameworthiness of Merely Reckless and Works Tonight.

Here is the principle of dependence:

\footnotetext{
${ }^{23}$ Crisp (2017, p. 18) considers this position, but ultimately rejects it.

${ }^{24}$ I choose Works Tonight instead of No Start to pair with Merely Reckless, because it is more obviously a case of circumstantial luck (see footnote 5).
} 
An agent is praiseworthy or blameworthy for an event only if the occurrence of that event at least partially depends on her free action or omission.

The event of Merely Reckless's driving drunk is an event that depends at least in part on her free choices or omissions. Even if Merely Reckless is too cognitively impaired to freely operate her vehicle at the time she is driving drunk, her moral responsibility for driving drunk plausibly traces back to (and so depends on) an earlier omission to make plans about how to get home safely. Of course, since Works Tonight does not drive drunk, no such event depends on her free action or omission, which precludes her blameworthiness for driving drunk. So, the principle of dependence provides a reason to think that Merely Reckless may be more blameworthy than Works Tonight, because it provides a necessary condition on moral responsibility that is satisfied in one case but not the other.

Here is the principle of fair opportunity:

An agent is praiseworthy for an exemplary action or blameworthy for a wrong action only if she had a fair opportunity to avoid performing the action. ${ }^{25}$

I leave it open whether we should understand 'fair opportunity' in a compatibilist way to include merely the agent's having normative competence and situational control (cf. Brink and Nelkin 2013) or in an incompatibilist way to include the agent's also having alternative possibilities at the moment of choice (cf. Otsuka 1998, 2009). We may stipulate that Merely Reckless had the relevant kind of fair opportunity to avoid driving drunk, because she could have freely chosen in the relevant sense to make different transportation preparations or not to drink at all. Since, however, Works Tonight does not have an opportunity to drive drunk, she does not have a fair opportunity of the relevant kind to avoid driving drunk, which rules out being blameworthy for driving drunk. (Of course, the more natural explanation for why Works Tonight is not blameworthy is that Works Tonight does not drive drunk. The point here is that there is an asymmetry with respect to a necessary condition on moral responsibility.) So, the principle of fair opportunity also provides a reason to think that Merely Reckless may be more blameworthy than Works Tonight.

Plausibly, satisfying these principles is what makes cases of circumstantial moral luck consonant with a fairness core of morality. It seems plausible that anyone moved by the fairness-based justification for the Asymmetry View would agree.

Importantly, the basic ideas in the principles of dependence and fair opportunity are satisfied also in the comparative case of Killer and Merely Reckless in such a way that they leave open the possibility of resultant moral luck. The event of killing the pedestrian by drunk driving depends on Killer's choice to drive drunk or traces back to a relevant past free action or omission, and thus Killer's deadly consequence satisfies the core idea behind the principle of dependence. And since Merely Reckless does not kill a pedestrian, no such event depends on her free action or

\footnotetext{
25 Philosophers such as Wolf (1990) and Nelkin (2011) who endorse an asymmetry in the conditions of praiseworthiness and blameworthiness may revise this principle as follows: an agent is blameworthy for a wrong action only if she had a fair opportunity to avoid performing the action.
} 
omission; thus, Merely Reckless cannot be additionally blameworthy for killing a pedestrian. Furthermore, Killer had a fair opportunity to avoid killing the pedestrian in part because she had a fair opportunity to avoid driving drunk; another part of what makes her opportunity to avoid killing the pedestrian a fair one is that the consequence of killing a pedestrian is a foreseeable result of drunk driving. But then, the same basic considerations that make circumstantial and constitutive moral luck benign on the Asymmetry View should also make foreseeable resultant moral luck benign too. ${ }^{26}$ Thus, if the principles of dependence and fair opportunity are what make circumstantial and constitutive moral luck fair in a certain way with respect to morality, then there is no good unfairness objection to foreseeable resultant moral luck, because the basic ideas behind those principles are satisfied also in cases of foreseeable resultant moral luck.

Furthermore, resultant moral luck does not involve involuntary moral risk in the way that circumstantial and constitutive moral luck do. Recall that because the agent often does not choose whether she finds herself in higher or lower stakes circumstances owing to her circumstantial and constitutive luck, the agent does not decide how much of a moral risk she wants to take with respect to doing the right thing. ${ }^{27}$ This kind of involuntary moral risk is not present in cases of resultant moral luck. Killer, for example, could easily have avoided being subject to the moral risk of causing the death of a pedestrian via drunk driving by forgoing the consumption of alcohol or by making foolproof plans to avoid driving. In general terms, if someone wants to avoid the moral risk involved with bad resultant moral luck, then she can avoid performing morally bad actions that have foreseeable bad consequences, and if a person wants a chance to have good resultant moral luck, then she should perform morally good actions that have foreseeable good consequences. Unlike in cases of circumstantial and constitutive moral luck, it is up to the agent what kinds of risks she takes with respect to resultant moral luck.

\section{Concluding thoughts}

I have argued that various intermediary positions in the moral luck debate - that is, positions that allow some kinds of moral luck to exist but deny others-are unmotivated according to the ideal of fairness, because there is no fairness-relevant moral reason to allow certain kinds of moral luck to exist and to deny others. The upshot is that philosophers who hold such intermediary views on grounds of fairness should either (1) embrace absolute fairness as the standard of morality, and so embrace either responsibility skepticism or Nagelian paradox, or (2) agree that there is no good objection to the existence of constitutive, circumstantial, and resultant moral luck on grounds of fairness. If philosophers who occupy these intermediary positions take route

\footnotetext{
${ }^{26}$ In Hartman (2017, pp. 90-93), I argue that all extant resultant moral luck is foreseeable resultant moral luck.

27 It is plausible that ease and difficulty of circumstances do affect degrees of praiseworthiness and blameworthiness (Nelkin 2016), even though they are not weighted precisely enough to provide equality of moral opportunity.
} 
(2), then at least some of them will have motivation to abandon their positions, because a prominent motivation for rejecting moral luck is on the grounds of fairness. And if they take route (2) — as I think they should - they would have reason to think that morality is not absolutely, subjunctively, or actually fair in the ways defined in this paper.

Even if morality is unfair in these ways, morality can retain a fairness core if some version of compatibilism or libertarianism is true. Compatibilism, the view that an action's being causally determined by past states of affairs and laws of nature does not itself rule out acting freely or responsibly, fits nicely with the position that constitutive, circumstantial, and resultant moral luck exist, because compatibilism amounts to the claim that causal moral luck is not incoherent. One interesting example of this is Paul Russell's (2017) work. It is, however, less obvious that accepting constitutive, circumstantial, and resultant moral luck fits well with incompatibilism, which implies that causal moral luck cannot exist. ${ }^{28}$ Could there be a fairness-relevant moral reason for the incompatibilist to deny causal moral luck, and yet affirm constitutive, circumstantial, and resultant moral luck? There may be such a reason if alternative possibilities at the moment of choice are required to furnish the agent with a fair opportunity to avoid performing certain actions. I am merely pointing to what may be a fairness-relevant moral reason for why causal moral luck cannot exist but constitutive, circumstantial, and resultant moral luck can. In future work, I will explore the idea that libertarians should accept the unfairness of morality, and so accept resultant, circumstantial, and constitutive moral luck. ${ }^{29}$

Acknowledgements I am grateful to Joel Archer, Gunner Björnsson, Corey Katz, Rik Peels, Kristin Mickelson, Paul Russell, Philipp Schwind, András Szigeti, Caroline Touborg, and one anonymous referee for this journal for comments on this paper.

Open Access This article is distributed under the terms of the Creative Commons Attribution 4.0 International License (http://creativecommons.org/licenses/by/4.0/), which permits unrestricted use, distribution, and reproduction in any medium, provided you give appropriate credit to the original author(s) and the source, provide a link to the Creative Commons license, and indicate if changes were made.

\section{Appendix: The unfairness of morality}

There are at least five ways in which morality is unfair concerning moral properties other than deserving praise and blame. First, different luck can generate differences in what people are responsible for, because luck affects the scope of an agent's responsibility, even if we suppose that luck does not affect her degree of moral responsibility (Peels 2015; Zimmerman 2002). It is Killer's bad luck that makes him

\footnotetext{
${ }^{28}$ Russell (2008, p. 318) appears to assert that incompatibilism and the absolute fairness conception of morality necessarily go together. But it seems wrong that if one accepts incompatibilism, then one must also affirm the absolute fairness conception of morality.

29 In Hartman (unpublished manuscript), I explore the motivation that libertarians have for accepting resultant moral luck with respect to character-necessitated actions such as Martin Luther's famous refusal to recant his theological position: "Here I stand. I can do no other."
} 
morally responsible for more events-namely, the killing of a pedestrian - than Merely Reckless. The same goes for Merely Reckless's being morally responsible for more things than No Start, Works Tonight, and Scarred Childhood, and for No Start's being morally responsible for more things than Works Tonight and Scarred Childhood. Morality, then, is unfair with respect to that for which an agent is morally responsible. ${ }^{30}$

Second, different luck can generate different deontic or virtue-based imperatives. Even if there is no resultant moral luck, Killer's bad luck would still create moral obligations or virtuous directives to take responsibility for killing the pedestrian and to repair the moral damage that she has caused as far as it is reasonable and in her power (Hartman 2017, pp. 92, 93; Enoch 2012; Wolf 2001). ${ }^{31}$ That is, Killer ought to apologize to the family of the one she killed and to find other ways to make amends. Merely Reckless, of course, does not have these particular obligations, because she does not kill a pedestrian. Thus, morality is unfair with respect to what deontic or virtue-theoretic imperatives an agent has. ${ }^{32}$

Third, different luck can generate differences in moral taint. As Marina Oshana (2006, p. 355, 356) describes, an entity is tainted if it is altered in a way that eliminates some of its valuable features: "One is said to be morally tainted when one's moral personality has been compromised by the introduction of something that produces disfigurement of the moral psyche." Consider another variation on the case of the reckless driver. No Fault, a sixth character, performs perfectly behind the wheel, but she kills a child who emerges from a pile of leaves. Clearly, No Fault is not blameworthy for killing the child, because her driving is not faulty in any way. Nevertheless, we expect No Fault to experience guilt, shame, remorse, and regret about killing the child - that is, to feel what Williams (1981, pp. 28, 29) famously calls "agent regret." No Fault is morally tainted by the way in which killing the child shatters her positive self-image, alienates her from herself, and stigmatizes her as a child killer. Of course, Merely Reckless does not acquire moral taint of this kind or degree, even though it is plausible to say that her blameworthy action taints her in some way (Stump 2004). Furthermore, people can acquire moral taint through bad circumstantial and constitutive luck. In the novel Sophie's Choice, the Nazis force Sophie to make a decision about which of her two children should live, and her refusal to choose would amount to the death of both; she opts to preserve one life and later commits suicide on account of the crushing guilt. Moreover, even innocent children of prominent Nazi officers experienced guilt and shame due to the way in which their practical identities were related to shameful persons and events (Sereny 2001). Thus, morality is unfair with respect to whether a person acquires moral taint.

\footnotetext{
30 This is true especially in cases of collective responsibility in which a person is a contributor to an outcome that might not have turned out to be bad but for the independent contributions of others (see Szigeti 2014).

31 Haji (2016) argues that if constitutive luck precludes the ability to do otherwise, then we do not have moral obligations either.

32 A potential further source of unfairness would be moral dilemmas set up by conflicting "nonnegotiable" moral obligations (Tessman 2014, Ch. 1; Nagel 1979, p. 34n9).
} 
Fourth, different luck can generate differences in being a good or bad person. Nagel (1979, p. 26) provides a famous example of the way in which diachronic circumstantial luck can affect whether we become better or worse persons:

Someone who was an officer in a concentration camp might have led a quiet and harmless life if the Nazis had never come to power in Germany. And someone who led a quiet and harmless life in Argentina might have become an officer in a concentration camp if he had not left Germany for business reasons in 1930.

In fact, recent work in social psychology, the so-called situationist literature, supports the claim that the circumstances in which we find ourselves matter a lot more than we have previously thought for being a good or bad person, because almost all of us would do bad things in certain circumstances (Doris 2002; Miller 2013). Furthermore, certain kinds of capacity-related constitutive luck can set up people to become bad. A familiar characterization of a psychopath, for example, involves the inability to tell the difference between moral and conventional rules, and a lack of various emotions such as empathy. Thus, psychopaths are not able to appreciate the respective strengths that moral and conventional reasons should have in their deliberations. This lack of normative competence makes them more likely to engage in egoistic behavior and so to become worse persons (Shoemaker 2015). Thus, morality is unfair with respect to the degree to which an agent is a good or bad person, and even whether someone is a good or bad person.

Finally, different luck can generate differences in flourishing. Human flourishing involves appreciating beauty, engaging in projects, having good relationships, possessing good character, being free, and having knowledge to name just a few features of the good life. Bad luck can compromise flourishing by depriving a person of the means to participate in those activities; for example, a person might acquire chronic fatigue syndrome and thereby have to withdraw from family, friendships, work, hobbies, and religious activities. Bad luck can also dislodge some of the agent's valuable properties related to her flourishing. For example, an agent may lose freedom due to enslavement, lose knowledge and self-direction due to amnesia or Alzheimer's disease, or lose good character due to traumatic events (Nussbaum 2001, p. 328). Furthermore, different luck can generate differences in desert of flourishing. If we deserve to flourish in proportion to our moral virtue and whether we are morally virtuous is affected by luck, ${ }^{33}$ the degree to which one deserves to flourish is also subject to luck. Thus, morality is also unfair with respect to how well people flourish, and perhaps also how much people deserve to flourish.

\section{References}

Adams, M. M. (1999). Horrendous evils and the goodness of God. Ithaca: Cornell University Press.

\footnotetext{
33 Adams (1999, p. 125) and Adams (2006, p. 163) both assert that the moral virtue is not within reach of all persons.
} 
Adams, R. (2006). A theory of virtue: Excellence in being for the good. Oxford: Oxford University Press.

Anderson, M. (2011). Open theism, molinism, and soteriological luck. Religious Studies, 47(3), 371-381.

Anderson, M. (forthcoming). Moral luck as moral lack of control. Southern Journal of Philosophy.

Brink, D. O., \& Nelkin, D. K. (2013). Fairness and the architecture of responsibility. In D. Shoemaker (Ed.), Oxford studies in agency and responsibility (Vol. 1). Oxford: Oxford University Press.

Church, I. M. \& Hartman, R. J. (Eds.) (forthcoming). The routledge handbook of the philosophy and psychology of luck. New York: Routledge.

Coffman, E. J. (2015). Luck: Its nature and significance for human knowledge and agency. New York: Palgrave Macmillan.

Crisp, R. (2017). Moral luck and equality of moral opportunity. Aristotelian Society Supplementary, 91(1), 1-20.

Cushman, F., \& Greene, J. D. (2012). Finding faults: How moral dilemmas illuminate cognitive structure. Social Neuroscience, 7(3), 269-279.

Doris, J. (2002). Lack of character: Personality and moral behavior. Cambridge: Cambridge University Press.

Enoch, D. (2010). Moral luck and the law. Philosophy Compass, 5(1), 42-54.

Enoch, D. (2012). Being responsible, taking responsibility, and penumbral agency. In U. Heuer \& G. Lang (Eds.), Luck, value, and commitment: Themes from the ethics of Bernard Williams (pp. 95-132). Oxford: Oxford University Press.

Enoch, D., \& Marmor, A. (2007). The case against moral luck. Law and Philosophy, 26(4), 405-436.

Ferrante, M. (2009). Recasting the problem of resultant moral luck. Legal Theory, 15(4), 267-300.

Graham, P. A. (2014). A sketch of a theory of blameworthiness. Philosophy and Phenomenological Research, 88(2), 388-409.

Greco, J. (1995). A second paradox concerning responsibility and luck. Metaphilosophy, 26(1-2), 81-96.

Haji, I. (2016). Luck's mischief: Blameworthiness and obligation on a thread. Oxford: Oxford University Press.

Hanna, N. (2014). Moral luck defended. Noûs, 48(4), 683-698.

Hartman, R. J. (2017). In defense of moral luck: Why luck often affects praiseworthiness and blameworthiness. New York: Routledge.

Hartman, R. J. (forthcoming). Constitutive moral luck and Strawson's argument for the impossibility of moral responsibility. Journal of the American Philosophical Association.

Hartman, R. J. (unpublished manuscript). Indirectly free acts, libertarianism, and resultant moral luck.

Khoury, A. (2018). The objects of moral responsibility. Philosophical Studies, 175(6), 1357-1381.

Levy, N. (2011). Hard luck: How luck undermines free will and moral responsibility. Oxford: Oxford University Press.

Levy, N. (2014). Consciousness and moral responsibility. Oxford: Oxford University Press.

Mackenzie, J. (2017). Agent-regret and the social practice of moral luck. Res Philosophica, 94(1), 95-117.

McKenna, M. (2008). Putting the lie on the control condition for moral responsibility. Philosophical Studies, 139(1), 29-37.

Mele, A. (2006). Free will and luck. Oxford: Oxford University Press.

Miller, C. (2013). Moral character: An empirical theory. Oxford: Oxford University Press.

Moore, M. (1997). Placing blame: A general theory of criminal law. Oxford: Oxford University Press.

Nagel, T. (Ed.). (1979). Moral Luck. In Mortal questions (pp. 24-28). Cambridge: Cambridge University Press.

Nelkin, D. (2011). Making sense of freedom and responsibility. Oxford: Oxford University Press.

Nelkin, D. (2013). Moral luck. In E. N. Zalta (Ed.), The Stanford encyclopedia of philosophy. http://plato. stanford.edu/archives/win2013/entries/moral-luck/. Accessed October 19, 2017.

Nelkin, D. (2016). Difficulty and degrees of praiseworthiness and blameworthiness. Noûs, 50(2), 356-378.

Nussbaum, M. (2001). The fragility of goodness: Luck and ethics in Greek tragedy and philosophy (Revised ed.). Cambridge: Cambridge University Press.

Oshana, M. A. L. (2006). Moral taint. Metaphilosophy, 37(3-4), 353-375.

Otsuka, M. (1998). Incompatibilism and the avoidability of blame. Ethics, 108(4), 685-701.

Otsuka, M. (2009). Moral luck: Optional, not brute. Philosophical Perspectives, 23(1), 373-388.

Parker, R. (1984). Blame, punishment, and the role of result. American Philosophical Quarterly, 21(3), 269-276. 
Peels, R. (2015). The modal solution to the problem of moral luck. American Philosophical Quarterly, 52(1), 73-87.

Peels, R. (2017). Responsible belief: A theory in ethics and epistemology. Oxford: Oxford University Press.

Peels, R. (forthcoming). The mixed account of luck. In I. M. Church \& R. J. Hartman (Eds.), The routledge handbook of the philosophy and psychology of luck. New York: Routledge.

Rescher, N. (1993). Moral luck. In D. Statman (Ed.), Moral luck (pp. 141-166). Albany: State University of New York Press.

Rivera-López, E. (2016). How to reject resultant moral luck alone. Journal of Value Inquiry, 50(2), $415-423$.

Rosell, S. (2015). Moral luck and true desert. In A. Buckareff, C. Moya, \& S. Rosell (Eds.), Agency, freedom, and moral responsibility (pp. 116-133). New York: Palgrave Macmillan.

Rosen, G. (2002). Culpability and ignorance. Proceedings of the Aristotelian Society, 103(1), 61-84.

Russell, P. (2008). Free will, art, and morality. The Journal of Ethics, 12(3-4), 307-325.

Russell, P. (Ed.). (2017). The limits of free will: Selected essays. Oxford: Oxford University Press.

Sereny, G. (2001). Healing the wound: Experiences and reflections on Germany, 1938-2001. New York: W. W. Norton \& Company.

Sher, G. (2005). Kantian fairness. Philosophical Issues, 15(1), 179-192.

Shoemaker, D. (2015). Responsibility from the margins. Oxford: Oxford University Press.

Smith, A. (2005). Responsibility for attitudes: Activity and passivity in the mental life. Ethics, 115(2), 236-271.

Statman, D. (Ed.) (1993). Introduction. In Moral luck (pp. 1-34). Albany: State University of New York Press.

Statman, D. (forthcoming). The definition of luck and the problem of moral luck. In I. M. Church \& R. J. Hartman (Eds.), The routledge handbook of the philosophy and psychology of luck. New York: Routledge.

Strawson, G. (1994). The impossibility of moral responsibility. Philosophical Studies, 75(1-2), 5-24.

Stump, E. (2004). Personal relations and moral residue. History of the Human Sciences, 17(2-3), 33-57.

Swenson, P. (unpublished manuscript). A solution to the problem of moral luck.

Szigeti, A. (2014). Are individualist accounts of collective responsibility morally deficient? In A. Konzelmann Ziv \& H. B. Schmid (Eds.), Institutions, emotions, and group agents (pp. 329-342). Dordrecht: Springer.

Talbert, M. (2017). Akrasia, awareness, and blameworthiness. In P. Robichaud \& J. W. Wieland (Eds.), Responsibility: The epistemic condition (pp. 47-63). Oxford: Oxford University Press.

Tessman, L. (2014). Moral failure: On the impossible demands of morality. Oxford: Oxford University Press.

van Iwagen, P. (2002). Free will remains a mystery. In R. Kane (Ed.), The oxford handbook of free will (pp. 158-177). Oxford: Oxford University Press.

Wallace, R. J. (1994). Responsibility and the moral sentiments. Cambridge: Harvard University Press.

Waller, B. N. (2011). Against moral responsibility. Cambridge: MIT Press.

Williams, B. (Ed.) (1981). Moral luck. In Moral luck: Philosophical papers 1973-1980 (pp. 20-39). Cambridge: Cambridge University Press.

Williams, B. (1985). Ethics and the limits of philosophy. Cambridge: Harvard University Press.

Wolf, S. (1990). Freedom within reason. Oxford: Oxford University Press.

Wolf, S. (2001). The moral of moral luck. Philosophic Exchange, 31(1), 5-19.

Zagzebski, L. (1994). Religious luck. Faith and Philosophy, 11(3), 397-413.

Zimmerman, M. J. (1987). Luck and moral responsibility. Ethics, 97(2), 374-386.

Zimmerman, M. J. (1988). An essay on moral responsibility. Lanham: Rowman and Littlefield Publishers.

Zimmerman, M. J. (2002). Taking luck seriously. The Journal of Philosophy, 99(11), 553-576.

Zimmerman, M. J. (2015). Moral luck reexamined. In David Shoemaker (Ed.), Oxford studies in agency and responsibility (Vol. 3, pp. 136-159). Oxford: Oxford University Press. 